\title{
Assessment of Knowledge and Reported Practices of Mothers Regarding Food Handling Among Their Preschool Children in Abu-Tig District.
}

\author{
Amal E Mohammed ${ }^{1}$, Safaa A Mohammed ${ }^{2} \&$ Naglaa S Abd El-aty ${ }^{3}$. \\ 1. Nursing Specialist at Abu-tig Central Hospital Assiut City, Egypt. \\ 2. Professor of Community Health Nursing Assiut University, Egypt. \\ 3. Assistant Professor of Community Health Nursing Assiut University, Egypt.
}

\begin{abstract}
Children are at higher risk for food borne illnesses than adults. Aim: This study aimed to assess knowledge and reported practice of mothers with pre school children regarding food handling. Subjects and Methods: Descriptive cross sectional design used in this study. It was conducted at 4 villages in Abou-tig district selected by stratified random sample (Abu-tig, Duena, Elnekhela and Baker). The sample consisted of 787 mothers with preschool children. Data were collected within six months Tools: two tools were utilized. First tool: interview questionnaire sheet for assessing Socio demographic characteristics, home environment and mother's knowledge about food handling. Second tool: was used to assess the reported practices of mothers about food handling. Results: showed that $30.37 \pm 6.58$ were the mean \pm SD of age of the studied mothers, Also $43.3 \%$ of mothers had fair level of knowledge and $67.2 \%$ had satisfactory level of practice. Conclusion: It was concluded that less than half of mothers had fair level of knowledge about food handling. Recommendations: Educational programs to upgrade the level of mother`s knowledge and practices toward food handling.
\end{abstract}

\section{Keywords: Food Handling, Knowledge, Reported Practice \& Mothers.}

\section{Introduction}

Foodborne illness has a higher rate in families with young children. The primary food handlers (parents/ guardians) have the full responsibility of having the knowledge of proper food handling. Also they should knew the rules for avoiding cross contamination, that in turn lead to good preparation and full cooking, the proper cooked temperatures of each food item, and the proper ways for storing food can reduce the rate of foodborne illness in young children can be reduced through Understanding food safety techniques (Hamade, 2015 ).

There are some risk factors that make children more susceptible for foodborne illness as underdeveloped immune system, lower body Weight, less acidic stomach and lack of control over meal preparation. Foodborne illness can result in long term health consequences and even death, especially in young children. Approximately one half of reported Foodborne illness occurs in children and an estimated one-third of all related costs ( $\$ 2.3$ billion dollars per year) are due to illnesses in infants and children under the age of 10. (Meysenburg et al., 2014).

Food handlers can cause passive pathogen transmission from contaminated sources such as transmitting pathogens from raw meat to a ready to eat food. Also they may carry some human specific food- borne pathogens such as Hepatitis A, typhoid Salmonella, Staphylococcus aureus and Shigella in their hands, cuts or sores, mouth, skin and hair. They may also shed foodborne pathogens during the infectiousness period as E. coli and non-typhoidal Salmonella or during recovery period of a gastrointestinal sickness (Sharif et al., 2013).

Based on the Centers for Disease Control and Prevention, an estimated one in six Americans (or 48 million people) become sick, 128,000 are hospitalized, and 3000 die of foodborne illness yearly. The objectives of Healthy People 2020 include reducing infections in the general population caused by key pathogens commonly transmitted through food (Campylobacter, Shiga toxin producing E. coli, Listeria monocytogenes, Salmonella, Vibrio, Yersinia) and the incidence of post diarrheal hemolytic uremic syndrome (HUS) in children under five years of age ( Stenger et al., 2014).

Diarrheal illnesses are the major cause of morbidity in children, The Institute for Health Metrics and Evaluation (IHME) of the University of Washington reported that intestinal infectious diseases were responsible for $8.21 \%$ of all deaths in Egyptian children. In its most recent World Fact Book, the US Central Intelligence Agency (CIA) classified Egypt as "intermediate" in terms of the degree of risk of major infectious diseases, particularly foodborne and waterborne diseases (Aboubakr \& Goy al., 2019).

Food-borne illnesses can cause many diseases globally. The World Health Organization (WHO, 2010) estimated that about 1.8 million child die to ingestion of contaminated food and water. Food contamination is a widespread problem not only in 
developing countries, but also in developed industrialized countries (Thelwell-Reid, 2014).

The health effects of these foodborne illnesses are very severe and include Guillain-Barre syndrome, reactive arthritis, kidney failure, diabetes, neurological dysfunctions and even death. Although young children are more susceptible to foodborne illness compared to adults, they have limited control over their foodborne illness risks because parents or guardians usually prepare their meals (Lum et al., 2013).

Because many cases of foodborne diseases are a result of mishandling food in the home, community health nurses who visit families in their homes are in an excellent position to provide education for the persons in a family who are responsible for food handling and preparation. It is important to stress safety in all stages of food handling. This includes : what to look for when purchasing food at the store or market, how to store food in the home, the importance of good hand washing and clean utensils and surfaces for food preparation, proper cooking techniques (Lundy \& Janes, (2016).

Community health nurses play a major role in primary prevention of food handling illnesses. They also interview infected persons to help identify contacts placed at risk by exposure to infected individuals. They perform home visits to monitor persons under treatment and ensure compliance with the accepted treatment. Nurses employed in special setting may also engaged in epidemiological investigation of diseases or out breaks of recognized illness (Maurer\&Claudia,2013).

\section{Significance of the study}

Food handling is important in preventing food borne illnesses. Food borne diseases are an important cause of morbidity and mortality, $40 \%$ of the food borne disease burden was among children under five years of age (WHO,2015).The world health organization estimated that about 1.8 million child die yearly because of diarrhea (Thelwell-Reid, 2014).

At upper Egypt the incidence of hepatitis $\mathrm{A}$ in children aged 2-18 years is 13,8\% ( Hasan et al., 2016).

\section{Subjects \& Methods}

Aim of the study

- Assess knowledge and reported practices of mothers regarding food handling among preschool children in Abu-tig district.

\section{Research question}

- Dose mothers of preschool children have good knowledge and good practices regarding food handling?

\section{Research design}

Descriptive cross sectional research design was used in the current study to assess knowledge and reported practice of mothers regarding food handling.

\section{Setting}

The study was conducted at 3 randomly selected villages in Abou-tig district which is one from 11 districts of Assiut governorate. These villages are Bakoor, Elnekhela, Duena and Abou-tig city.

\section{Sample}

Abou-Tig is one of Assuit city districts, by using stratified random sample we select one village from each direction represented as Bakoor at the North, Elnekhela at the South, Duena at the West, and Abou-tig at the East. The total number of mothers having pre-school children in the selected villages was 30484. By using software EPI/Info, version 3.3 with 99\% confidence interval (CI) the estimated sample size was 650 mother. To compensate the drop outs, $20 \%$ was added to the sample size. The total sample size was 787 as following in the table, after getting the necessary approval to conduct the study from the administrator of the maternal and child health care center $(\mathrm{MCH})$ the study was conducted through interview of the selected mothers at home setting, as we randomly select the first house that have a mother of preschool child thereafter, we select every $3^{\text {rd }}$ house that have a mother of preschool child by using systematic random sampling for selecting the homes.

\begin{tabular}{|l|c|c|c|}
\hline Village & $\begin{array}{c}\text { Number } \\
\text { of } \\
\text { mothers }\end{array}$ & $\begin{array}{c}\text { Sample } \\
\text { size }\end{array}$ & Percent \\
\hline Abou-tig & 11960 & 312 & $40 \%$ \\
\hline Duena & 7702 & 195 & $25 \%$ \\
\hline El nekhela & 6077 & 156 & $20 \%$ \\
\hline Bakor & 4745 & 124 & $15 \%$ \\
\hline Total & 30484 & 787 & $100 \%$ \\
\hline
\end{tabular}

\section{Tool of the study}

structured interview questionnaire was developed by researcher after reviewing the relevant literature to collect information, it was include two tools.

Tool (1): It was included three parts:

Part 1

Socio demographic characteristics scale which developed by (Abd Eltwaab, 2014) it was included personal characteristics data of mothers (age, level of education, address, income, and number of preschool children).

Part 2

Home environment and sanitation such as (building material, ventilation, electric current, water resource, 
storing of water and food, method of drainage and disposal of garbage).

\section{Part3}

It was used to assess mother's knowledge about food handling such as: knowledge about cleanness, separation of food elements, cooking and chilling. And assessing mother's knowledge about definition of food borne disease, causes, diseases caused by food contamination, mode of transmission, risk factors that make child more susceptible to food borne diseases.

\section{The scoring system was as follow}

Part 3 used to assess of mother's knowledge about food handling. a score one was given for each correct answer and zero was given for incorrect answer. the total grades of knowledge equal (55): The grades for each item were summed and then converted into a percent score as following: Poor knowledge; Score less than $50 \%$, Fair knowledge; If score is from 50 $70 \%$ and Good knowledge ; If score more than $70 \%$ (AbdElzaher et al., 2014 \& Abd El-Rhman, 2014).

\section{Tool 2}

It was used to assess the reported practices of mothers about food handling such as: cleanliness during preparation of food, separation of food, cooking of food and preservation of food.

The scale has a total of 36 items of the 4 dimensions cleaning has 11 items equal 55 grades, separation has 9 items equal 45 grades, cooking has 8 items equal 40 grades, and chilling has 8 items equal 40 grades. The total grades of reported practices equal (180).

The Scoring System of reported practice: answers are on a Iikert scale 1 as "Never", 2 as "Rarely", 3 as "Some of the time", 4 as "Most of the time" and 5 as "Always". Not all items of the scale are positive presentation, but there are reversed items. The highest score the good food handling practices, the grades for each item were summed and then converted into a percent score as the following unsatisfactory $=$ score $<70 \%$, satisfactory $=$ score $\geq 70 \%$.

Validity of tool: The tools reviewed to ascertain their validity by panel of five experts in community health nursing science who reviewed for clarity, relevance, comprehensiveness, understanding and applicability.

Reliability of tool: A reliability analysis was carried out in order to examine the internal consistency of its questions. The value of Cronbach's Alpha was for knowledge (0.813) and for practice (0.747) and this implying that the instrument was consistent and reliable in achieving the study objectives.

\section{Methods}

I-Administrative design

An official letter approval obtained from dean of the Faculty of Nursing Assiut University to director of
Minister of Health in Assuit. This letter included a brief explanation of the objectives of the study.

\section{Ethical consideration}

Research proposal was approved from Ethical Committee in the Faculty of Nursing. $\square \square$ There was no risk for study subject during application of the research. The study was followed ethical principles in clinical research. Oral informed consent was obtained from studied sample that are willing to participate in the study, after explaining the nature and purpose of the study. Confidentiality and anonymity was assured. Studied sample have the right to refuse to participate and or withdraw from the study without any rational any time.

\section{II-Operational design Pilot Study}

A Pilot study was carried out on 78 mothers with preschool children (10\%). It was carried out to ensure clarity and applicability of the developed tools, identify the obstacles and problems that may encountered with data collection and estimate the time required to fill the questionnaire. Based on the results of the pilot study, there was no need for modifications.

\section{Data collection Phase}

Approval was obtained from dean of the Faculty of Nursing Assiut University to the head of authorized administration in Abou-tig $\mathrm{MCH}$ soliciting the necessary approval to conduct the present research on mothers with preschool children after explaining the aim and nature of the study to obtain their cooperation. Questionnaire questions were answered through home visits. Data was collected in the period from $9^{\text {st }}$ December, 2017 to $18^{\text {th }}$ May, 2018. The researchers introduce themselves and explain the purpose of the study for the studied sample. The average of time taken for completing each sheet was around 15-25 minutes depending on the persons' response to questions. Data was collected by the researcher for 3 days per week. About (10- 12) sheets/day.

\section{Statistical analysis}

Date entry and data analysis were done using SPSS version 19 (Statistical Package for Social Science). Data were presented as number, percentage, mean, standard deviation. Chi-square test was used to compare between qualitative variables. An independent sample t-test was used to compare quantitative variables between two groups and ANOVA test was used for more than two groups. Pearson correlation was done to measure correlation between quantitative variables. P-value considered statistically significant when $\mathrm{P}<0.05$. 


\section{Results}

Table (1): Distribution of preschool children's mothers according to their Socio demographic characteristics Abou-tig district, 2018, No (787).

\begin{tabular}{|c|c|c|}
\hline Variable & No. 787 & $\%$ \\
\hline \multicolumn{3}{|l|}{ Age: (years) } \\
\hline$<25$ & 140 & 17.8 \\
\hline $25-<30$ & 271 & 34.4 \\
\hline $30-<35$ & 123 & 15.6 \\
\hline$\geq 35$ & 253 & 32.2 \\
\hline Mean \pm SD (Range) & \multicolumn{2}{|c|}{$30.37 \pm 6.58(18.0-47.0)$} \\
\hline \multicolumn{3}{|l|}{ Number of pre-school children } \\
\hline One & 446 & 56.7 \\
\hline Two & 304 & 38.6 \\
\hline Three or more & 37 & 4.7 \\
\hline \multicolumn{3}{|l|}{ Mother's education } \\
\hline Illiterate & 33 & 4.2 \\
\hline Read \& write & 37 & 4.7 \\
\hline Basic education & 82 & 10.4 \\
\hline Secondary & 345 & 43.9 \\
\hline University & 223 & 28.3 \\
\hline Postgraduate & 67 & 8.5 \\
\hline \multicolumn{3}{|l|}{ Father's education } \\
\hline Illiterate & 56 & 7.1 \\
\hline Read \& write & 32 & 4.1 \\
\hline Basic education & 89 & 11.3 \\
\hline Secondary & 358 & 45.5 \\
\hline University & 216 & 27.4 \\
\hline Postgraduate & 36 & 4.6 \\
\hline \multicolumn{3}{|l|}{ Mother's occupation } \\
\hline Employee & 401 & 51.0 \\
\hline Housewife & 386 & 49.0 \\
\hline \multicolumn{3}{|l|}{ Father's occupation } \\
\hline Employee & 355 & 45.1 \\
\hline Farmer & 19 & 2.4 \\
\hline Skilled worker & 218 & 27.7 \\
\hline Unskilled worker & 115 & 14.6 \\
\hline Free business & 73 & 9.3 \\
\hline Dead & 7 & 0.9 \\
\hline \multicolumn{3}{|l|}{ Residence } \\
\hline Rural & 475 & 60.4 \\
\hline Urban & 312 & 39.6 \\
\hline \multicolumn{3}{|l|}{ Social class: (income) } \\
\hline Low & 211 & 26.8 \\
\hline Middle & 415 & 52.7 \\
\hline High & 161 & 20.5 \\
\hline
\end{tabular}


Table (2): Mean score of knowledge for studied mothers regarding food handling, Abou-tig district, 2018.

\begin{tabular}{|l|c|c|c|}
\hline & Max. Score & Mean \pm SD & Range \\
\hline Knowledge about foodborne diseases & 16 & $6.96 \pm 2.94$ & $3.0-16.0$ \\
\hline Knowledge about hygiene during food preparation & 10 & $8.82 \pm 1.59$ & $4.0-10.0$ \\
\hline Knowledge about food separation & 6 & $5.05 \pm 1.46$ & $0.0-6.0$ \\
\hline Knowledge about cooking food & 11 & $5.36 \pm 1.94$ & $1.0-10.0$ \\
\hline Knowledge about food preservation & 12 & $6.23 \pm 1.54$ & $2.0-11.0$ \\
\hline Total score of knowledge & 55 & $32.42 \pm 6.44$ & $18.0-49.0$ \\
\hline
\end{tabular}

Table (3): Reported practice of preschool children's mothers regarding cleaning during preparing food, Abou-tig district, 2018, No (787).

\begin{tabular}{|l|l|l|l|l|l|l|l|l|l|l|}
\hline \multicolumn{1}{|c|}{ Items of Reported practice } & \multicolumn{2}{|c|}{ Always } & \multicolumn{2}{|c|}{$\begin{array}{c}\text { Most of } \\
\text { the time }\end{array}$} & \multicolumn{2}{|c|}{ Sometime } & \multicolumn{2}{|c|}{ Rarely } & \multicolumn{2}{|c|}{ Never } \\
\cline { 2 - 11 } & No. & $\%$ & No. & $\%$ & No. & $\%$ & No. & $\%$ & No. & $\%$ \\
\hline $\begin{array}{l}\text { Washing hands with soap and } \\
\text { running water before and after } \\
\text { preparing food, and even snacks } \\
\text { for at least 20 seconds. }\end{array}$ & 492 & 62.5 & 220 & 28.0 & 75 & 9.5 & 0 & 0.0 & 0 & 0.0 \\
\hline $\begin{array}{l}\text { Drying hands with unclean towel } \\
\text { after washing them with soap and } \\
\text { water }\end{array}$ & 79 & 10.0 & 52 & 6.6 & 117 & 14.9 & 124 & 15.8 & 415 & 52.7 \\
\hline $\begin{array}{l}\text { Washing hands with soap and } \\
\text { warm water after cracking raw } \\
\text { eggs and after dealing with raw } \\
\text { meat. }\end{array}$ & 402 & 51.1 & 161 & 20.5 & 148 & 18.8 & 50 & 6.4 & 26 & 3.3 \\
\hline $\begin{array}{l}\text { Rinsing fresh fruits and vegetables } \\
\text { completely under tap water with } \\
\text { rubbing. }\end{array}$ & 479 & 60.9 & 226 & 28.7 & 63 & 8.0 & 12 & 1.5 & 7 & 0.9 \\
\hline $\begin{array}{l}\text { Washing children`s hands with } \\
\text { soap and running water before } \\
\text { helping me in the kitchen or } \\
\text { putting food on the table. }\end{array}$ & 386 & 49.0 & 200 & 25.4 & 188 & 23.9 & 13 & 1.7 & 0 & 0.0 \\
\hline $\begin{array}{l}\text { Washing hands of my children } \\
\text { with soap and running water } \\
\text { before a snack or a basic meal. }\end{array}$ & 501 & 63.7 & 181 & 23.0 & 93 & 11.8 & 12 & 1.5 & 0 & 0.0 \\
\hline $\begin{array}{l}\text { Washing hands after playing with } \\
\text { a pet with soap and water. }\end{array}$ & 430 & 54.6 & 132 & 16.8 & 102 & 13.0 & 111 & 14.1 & 12 & 1.5 \\
\hline $\begin{array}{l}\text { Disinfecting the food preparation } \\
\text { area with disinfectant as chlorine. }\end{array}$ & 257 & 32.7 & 203 & 25.8 & 133 & 16.9 & 154 & 19.6 & 40 & 5.1 \\
\hline $\begin{array}{l}\text { Covering the head during food } \\
\text { preparation. }\end{array}$ & 235 & 29.9 & 240 & 30.5 & 138 & 17.5 & 95 & 12.1 & 79 & 10.0 \\
\hline $\begin{array}{l}\text { Make sure that there are no } \\
\text { smokers in the food preparation } \\
\text { area. }\end{array}$ & 291 & 37.0 & 184 & 23.4 & 203 & 25.8 & 51 & 6.5 & 58 & 7.4 \\
\hline $\begin{array}{l}\text { Washing hands with soap and } \\
\text { water after changing diapers. }\end{array}$ & 687 & 87.3 & 82 & 10.4 & 18 & 2.3 & 0 & 0.0 & 0 & 0.0 \\
\hline
\end{tabular}




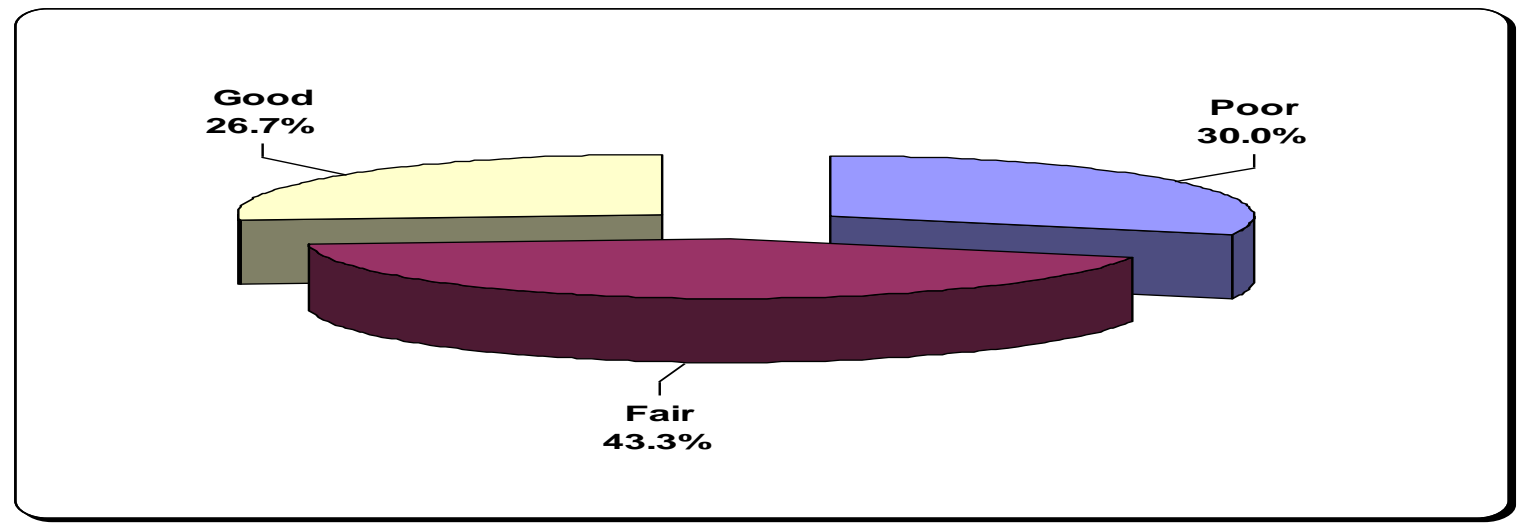

Figure (1): Total score of the studied preschool children`s mothers knowledge about food handling.

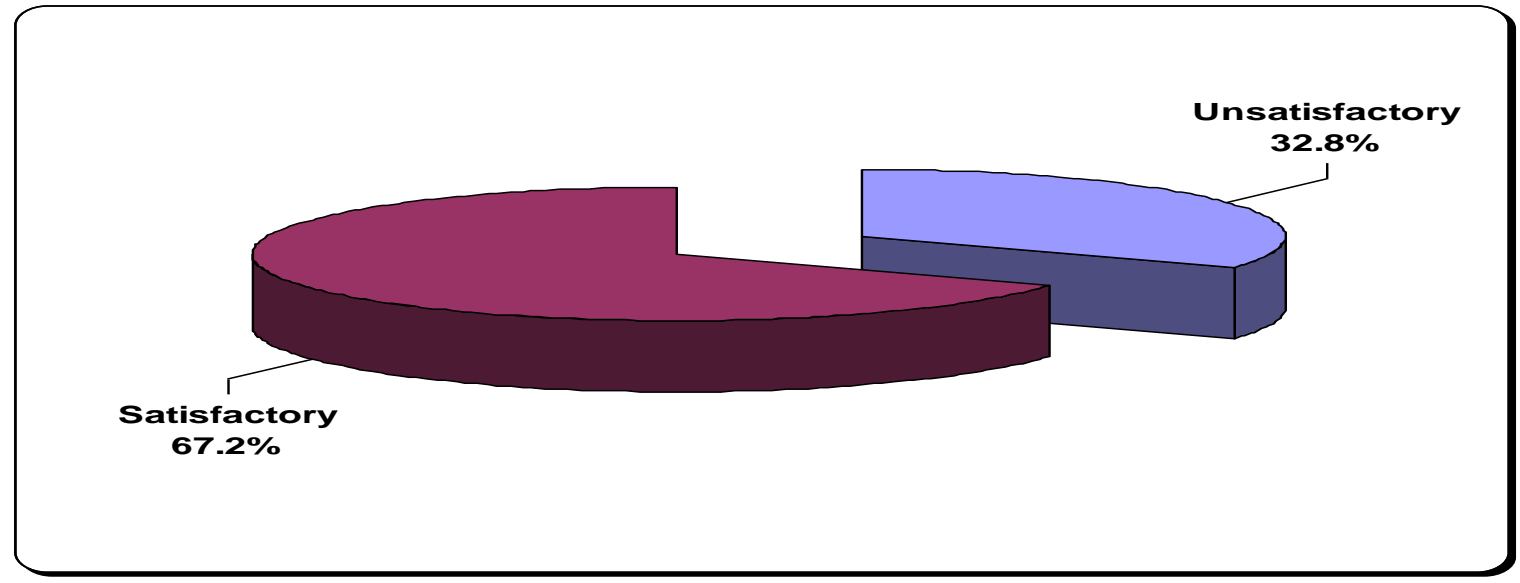

Figure (2): Total score of the reported practice among studied preschool children's mothers about food handling.

Table (4): Relationship between some socio demographic characteristics of preschool children's mothers and their total score of knowledge regarding food handling Abou-tig district, 2018 (No.787).

\begin{tabular}{|c|c|c|c|c|c|c|c|}
\hline & \multicolumn{6}{|c|}{ Level of knowledge } & \multirow{3}{*}{ P-value } \\
\hline & \multicolumn{2}{|c|}{ Good } & \multicolumn{2}{|c|}{ Fair } & \multicolumn{2}{|c|}{ Poor } & \\
\hline & No. & $\%$ & No. & $\%$ & No. & $\%$ & \\
\hline Age: (years) & & & & & & & \multirow{5}{*}{$0.000 *$} \\
\hline$<25$ & 19 & 13.6 & 82 & 58.6 & 39 & 27.9 & \\
\hline $25-<30$ & 117 & 43.2 & 82 & 30.3 & 72 & 26.6 & \\
\hline $30-<35$ & 31 & 25.2 & 43 & 35.0 & 49 & 39.8 & \\
\hline$\geq 35$ & 43 & 17.0 & 134 & 53.0 & 76 & 30.0 & \\
\hline \multicolumn{7}{|c|}{ Number of pre-school children } & \multirow{3}{*}{$0.026^{*}$} \\
\hline One & 105 & 23.5 & 193 & 43.3 & 148 & 33.2 & \\
\hline Two or more & 105 & 30.8 & 148 & 43.4 & 88 & 25.8 & \\
\hline \multicolumn{7}{|l|}{ Mother education } & \multirow{5}{*}{$0.000 *$} \\
\hline Illiterate/ Read \& write & 0 & 0.0 & 32 & 45.7 & 38 & 54.3 & \\
\hline Basic education & 6 & 7.3 & 24 & 29.3 & 52 & 63.4 & \\
\hline Secondary & 73 & 21.2 & 146 & 42.3 & 126 & 36.5 & \\
\hline University and higher & 131 & 45.2 & 139 & 47.9 & 20 & 6.9 & \\
\hline \multicolumn{7}{|l|}{ Father education } & \multirow{3}{*}{$0.000 *$} \\
\hline Illiterate/ Read \& write & 0 & 0.0 & 50 & 56.8 & 38 & 43.2 & \\
\hline Basic education & 12 & 13.5 & 32 & 36.0 & 45 & 50.6 & \\
\hline
\end{tabular}




\begin{tabular}{|c|c|c|c|c|c|c|c|}
\hline & \multicolumn{6}{|c|}{ Level of knowledge } & \multirow{5}{*}{ P-value } \\
\hline & \multicolumn{2}{|c|}{ Good } & \multicolumn{2}{|c|}{ Fair } & \multicolumn{2}{|c|}{ Poor } & \\
\hline & No. & $\%$ & No. & $\%$ & No. & $\%$ & \\
\hline Secondary & 81 & 22.6 & 150 & 41.9 & 127 & 35.5 & \\
\hline University and higher & 117 & 46.4 & 109 & 43.3 & 26 & 10.3 & \\
\hline \multicolumn{7}{|l|}{ Mother occupation } & \multirow{3}{*}{$0.000 *$} \\
\hline Employee & 160 & 39.9 & 179 & 44.6 & 62 & 15.5 & \\
\hline Housewife & 50 & 13.0 & 162 & 42.0 & 174 & 45.1 & \\
\hline \multicolumn{7}{|l|}{ Residence } & \multirow{3}{*}{0.609} \\
\hline Rural & 121 & 25.5 & 211 & 44.4 & 143 & 30.1 & \\
\hline Urban & 89 & 28.5 & 130 & 41.7 & 93 & 29.8 & \\
\hline \multicolumn{7}{|l|}{ Social class:(income) } & \multirow{4}{*}{$0.000 *$} \\
\hline Low & 7 & 3.3 & 88 & 41.7 & 116 & 55.0 & \\
\hline Middle & 118 & 28.4 & 188 & 45.3 & 109 & 26.3 & \\
\hline High & 85 & 52.8 & 65 & 40.4 & 11 & 6.8 & \\
\hline
\end{tabular}

Table (5): Relationship between some socio demographic characteristics of preschool children's mothers and their total score of reported practice regarding food handling Abou-tig district, 2018 (No.787).

\begin{tabular}{|c|c|c|c|c|c|}
\hline \multirow{3}{*}{ Variable } & \multicolumn{4}{|c|}{ Level of reported practices } & \multirow{3}{*}{ P-value } \\
\hline & \multicolumn{2}{|c|}{ Unsatisfactory } & \multicolumn{2}{|c|}{ Satisfactory } & \\
\hline & No. & $\%$ & No. & $\%$ & \\
\hline Age: (years) & & & & & \multirow{5}{*}{$0.001 *$} \\
\hline$<25$ & 62 & 44.3 & 78 & 55.7 & \\
\hline $25-<30$ & 78 & 28.8 & 193 & 71.2 & \\
\hline $30-<35$ & 48 & 39.0 & 75 & 61.0 & \\
\hline$\geq 35$ & 70 & 27.7 & 183 & 72.3 & \\
\hline \multicolumn{5}{|c|}{ Number of pre-school children } & \multirow{3}{*}{0.974} \\
\hline One & 146 & 32.7 & 300 & 67.3 & \\
\hline Two or more & 112 & 32.8 & 229 & 67.2 & \\
\hline \multicolumn{5}{|l|}{ Mother education } & \multirow{5}{*}{$0.000^{*}$} \\
\hline Illiterate/ Read \& write & 38 & 54.3 & 32 & 45.7 & \\
\hline Basic education & 57 & 69.5 & 25 & 30.5 & \\
\hline Secondary & 92 & 26.7 & 253 & 73.3 & \\
\hline University and higher & 71 & 24.5 & 219 & 75.5 & \\
\hline \multicolumn{5}{|l|}{ Father education } & \multirow{5}{*}{$0.000 *$} \\
\hline Illiterate/ Read \& write & 38 & 43.2 & 50 & 56.8 & \\
\hline Basic education & 51 & 57.3 & 38 & 42.7 & \\
\hline Secondary & 119 & 33.2 & 239 & 66.8 & \\
\hline University and higher & 50 & 19.8 & 202 & 80.2 & \\
\hline \multicolumn{5}{|l|}{ Mother occupation } & \multirow{3}{*}{$0.000 *$} \\
\hline Employee & 82 & 20.4 & 319 & 79.6 & \\
\hline Housewife & 176 & 45.6 & 210 & 54.4 & \\
\hline \multicolumn{5}{|l|}{ Residence } & \multirow{3}{*}{$0.000^{*}$} \\
\hline Rural & 191 & 40.2 & 284 & 59.8 & \\
\hline Urban & 67 & 21.5 & 245 & 78.5 & \\
\hline \multicolumn{5}{|l|}{ Social class: (income) } & \multirow{4}{*}{$0.000 *$} \\
\hline Low & 120 & 56.9 & 91 & 43.1 & \\
\hline Middle & 108 & 26.0 & 307 & 74.0 & \\
\hline High & 30 & 18.6 & 131 & 81.4 & \\
\hline
\end{tabular}




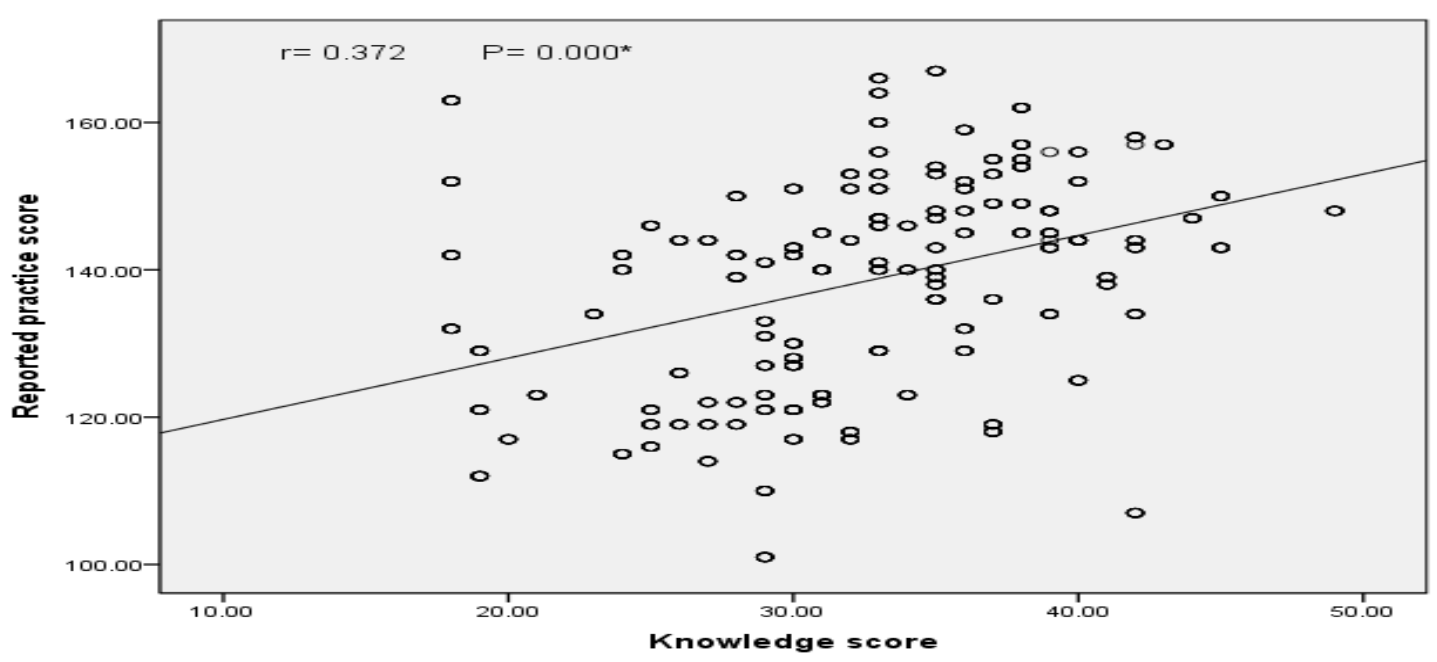

Fig (3): Shows the correlation between score of knowledge of studied preschool children`s mothers and their reported practice.

Table (1): Shows socio-demographic characteristics of the studied preschool children's mothers, it was found that, $34.4 \%$ of the studied mothers their age range from $(25-<30)$ years old with mean $\pm \mathrm{SD}$ (Range) $30.37 \pm 6.58$. Regarding to mother's education it was found that more than two fifths $(43.9 \%)$ of them had secondary education. concerning mother's occupation it was observed that more than half $(51 \%)$ of studied preschool children`s mothers were employed. Regarding to their social class more than half $(52.7 \%)$ of studied preschool children's mothers were in the middle level of social class.

Table (2): This table showed the mean score of knowledge for studied mothers regarding food handling. It was founded that Mean \pm SD of knowledge about foodborne diseases $6.96 \pm 2.94$, Mean \pm SD of knowledge about hygiene during food preparation was $8.82 \pm 1.59$, Mean $\pm \mathrm{SD}$ of knowledge about food separation was $5.05 \pm 1.46$, Mean \pm SD of knowledge about cooking of food was $5.36 \pm 1.94$, Also Mean \pm SD of knowledge about Chill concept was $6.23 \pm 1.54$

Table (3): Clarifies the reported practice of the studied preschool children`s mothers regarding cleanliness during food preparation, it was found that $62.5 \%$ of studied mothers always washed hands with soap and running water before and after preparing food, and even snacks for at least 20 seconds, $60.9 \%$ of preschool children's mothers always rinse fresh fruits and vegetables completely under tap water with rubbing, including those with skins and rinds that are not eaten like oranges, mandarins.

Table (4): This table illustrates the relationship between socio demographic characteristics of preschool children's mothers and their total score of knowledge regarding food handling. This table observes that there is significant difference between all items of socio demographic characteristics of studied preschool children's mothers and their level of knowledge regarding food handling $\mathrm{p}=0.000$, $0.026,0.000,0.000,0.000$ except one not significant residence (0.609).

Table (5): This table explains the relationship between socio demographic characteristics of studied preschool children`s mothers and their total score of reported practice regarding food handling. This table detects that there is significant difference between all items of socio demographic characteristics of studied preschool children's mothers and their level of reported practice regarding food handling $\mathrm{p}=0.001$, $0.000,0.000,0.000$ except one not significant number of preschool children 0.974 .

Fig (1): This figure illustrates that more than two fifths $(43.3 \%)$ of the studied preschool children's mothers had fair knowledge about food handling and more than one quarter $(26.7 \%)$ of them had good knowledge.

Fig (2): This figure showed that little more than two thirds $(67.2 \%)$ of the studied preschool children's mothers have satisfactory level of reported practice regarding food handling.

Fig (3): It was found that there was positive correlation between knowledge score and reported practice score.

\section{Discussion}

Food handlers that fail to perform the basic rule of food preparation such as mistreatment of the food and lack can hygiene practice contributed to of food 
poisoning. Therefore Food safety is a principal consideration in administering the food chain and an essential aspect in protecting the nation's health (Ismail et al., 2016).

Foodborne illnesses are linked to improper food handling practices that promote the growth and spread of microorganisms. Children are at a high risk for developing foodborne illness since their immune systems are not yet fully developed to fight pathogens. The lack of proper cleaning of food, preparation areas, and cooking utensils used in the home kitchen is likely to increase crosscontamination from poultry, meats, eggs, and readyto-eat foods (Hamade, 2015), therefore the present study aimed to assess the knowledge and the reported practice of mothers with pre school children regarding food handling.

The results of the current study showed that more than one third of the studied mothers their age more than 35 years old, this finding in line with (Meysenburg et al., 2014) who found that less than one third of the primary food preparers their age more than 35 years old, Also this result was inconsistent with (Alqurashi et al., 2019) who found that more than half of the studied sample aged 20-30 years old.

Regarding to mother's education it was found that more than one quarter of the studied mothers their education is university education, this result is in line with (Alqurashi et al., 2019) who found that less than one third of the studied sample have high school education.

Concerning to mother's occupation it is cleared that around half of the studied mothers were house wife this finding in same line with (Stenger et al., 2014) who found that less than half of the studied mothers were un employed.

Concerning to total score of knowledge of preschool children's mothers regarding food handling the present study was founded that less than half of the studied mothers have fair level of knowledge. This finding was similar to (Mendagudali et al., 2016) who found that less than half of the studied women have average level of knowledge.

Regarding mother's reported practice of washing hands with soap and running water before and after preparing food, and even snacks for at least 20 seconds the present study found that about two thirds of the studied mothers mention always that is in line with (Pilar et al., 2014) who found that more than two thirds and less than one third of the studied sample respectively report every time without fail and most of the time respectively, it was in line with (Mahmoud et al., 2010) who found that the majority of her studied sample washing hands before preparation of food.

Regarding to mother's reported practice of washing hands with soap and warm water after cracking raw eggs and after dealing with raw meat the finding of the existing study was Similar with (Lum et al., 2013) who found that more than two thirds of the studied sample reported always I wash my hands with warm soapy water after cracking open raw eggs

Regarding to mother's reported practice of washing hands with soap and water after changing diapers the present study was agree with (Asmawi et al., 2018) who found that the majority of the studied sample were always wash your hands after returning from the washroom.

Regarding to mother's reported practice of putting cooked meat on the same plate where the raw meat are present the present study found that about two thirds of the studied mothers report never that was similar to (Sani et al., 2014) who found that more than two thirds of the studied sample were concerned about food hygiene and prevention of crosscontamination between raw and cooked foods.

Regarding the mother's reported practice of after cutting raw meat, wash the knife with hot water and soap and then rinse with water the present study found that about two thirds of the studied mothers report always that was near to (Parra et al., 2014) who found that fifth of the studied sample report washed with soap or bleach and continue to use it.

Regarding the mother`s reported practice of placing raw meat over the ready to eat foods in the refrigerator the present study was parallel to (Lum et al., 2013) who found that about two thirds of the studied sample report never.

Concerning the mother's reported practice of placing raw meat in a packaging bag before placing it in the refrigerator the present study revealed that more than half mention always that is in line with (Siau et al., 2015) who found that more than half mention never of I do not separate the storage of raw food with cooked food.

Regarding the relationship between knowledge level and socio demographic characteristics their was similarity between the present study and (McIntyre et al., 2013) who found that there was significant difference $(p<0.0001, p<0.0001)$ between knowledge score with age and education respectively, that's because whenever the mother have good educational level she certainly have good knowledge.

Also this result is similar to (Alqurashi et al., 2019) who founded that their was significant difference between age group and educational level $(\mathrm{p}<0.00, \mathrm{p}$ $<0.00)$ respectively with food safety knowledge, also the present study found that the residence was not 
significant with the level of knowledge of the studied preschool children mothers that's because the residence not necessarily affect the knowledge of mothers about food handling because of the availability of knowledge resources like as media, primary health care centers which play a major role in educating mothers all issues regarding child caring through home visit so rural and urban mothers consider equal in knowledge about food handling.

The present study founded that there was significant difference between age group and educational level ( $\mathrm{p}<0.001, \mathrm{p}<0.000)$ respectively with food safety reported practice. This result is in the same line with (Alqurashi et al., 2019) who founded that their was significant difference between age group and educational level $(\mathrm{p}<0.10, \mathrm{p}<0.00)$ respectively with food safety reported practice, that's because whenever the mother get older she can do good practice.

The present study was founded that less than half of the studied mothers have fair level of knowledge. This finding was similar to (Mendagudali et al., 2016) who found that less than half of the studied women have average level of knowledge.

The present study was founded that more than tow thirds of the studied mothers have satisfactory level of reported practices. This finding was similar to (Mendagudali et al., 2016) who found that more than three quarters of the studied women have good level of reported practices.

The present study indicate a significant positive correlation $(\mathrm{P}=0.000)$ between knowledge score and reported practice score, this finding was similar to (Alqurashi et al., 2019) who found that there was a significant positive correlation $(p \leq 0.01)$ between food safety knowledge and food safety practices. the present study indicated that food safety knowledge could statistically predict food safety practices that's because the food handling knowledgeable mother can easily do good practice during food handling better than others mothers who don't have knowledge about food handling.

\section{Conclusions}

According to the finding and reassessed question. it was concluded that less than half of studied preschool children's mothers had fair level of knowledge and more than one quarter of them had good level of knowledge regarding food handling. Also more than two thirds of them had satisfactory level of practice toward food handling.

\section{Recommendations}

- Health education programs regarding food handling should be implemented for increasing awareness of mothers to prevent foodborne diseases and its consequences.

- Guide book should be distributed to all preschool mothers.

- Further researches are needed to test and verify the discrepancy of families behavior regarding food handling.

- The nurse must share in increasing awareness of mothers and their families about food handling.

\section{References}

1. Abd El-Rhman M., (2014): Knowledge and opinions of Assiut university students toward organ donation and transplantation, submitted for partial fulfillment of the requirement of the master degree in community health nursing, faculty of Nursing, Assiut university PP60-61.

2. AbdElzaher, O., Qayed, M., Mohamed, S., \& Mohamed, A., (2014): Farmer's knowledge, attitude and practice about pesticides in a village of abnub district. Assiut Governorate. Thesis Master Degree in Community Health Nursing at Faculty of Nursing. Assiut University.

3. Aboubakr H., \& Goyal S., (2019): Involvement of Egyptian Foods in Foodborne Viral Illnesses: The Burden on Public Health and Related Environmental Risk Factors: An Overview, Food and Environmental Virology. Vol 11Issue 4, Pp 315-339.

4. Alqurashi, N., Priyadarshini, A., \& Jaiswal, A., (2019): Evaluating Food Safety Knowledge and Practices among Foodservice Staff in Al Madinah Hospitals, Saudi Arabia, Safety VOL. 5, 9PP.119.

5. Hamade N., (2015): A Questionnaire based analysis of the food safety knowledge of primary food handlers for children eight years old and younger.proQuest available at http://gateway.proquest.com/openurl?url_ver=Z3 9.88-

2004\&res_dat=xri:pqdiss\&rft_val_fmt=info:ofi/f mt:kev:mtx:dissertation\&rft_dat=xri:pqdiss: 1605 454

6. Hasan G., Assiri A., Mrzuuk N., Daef E., Abdelwahab S., Ahmed A., Mohamad I., AlEyadhy A., Alhaboob A., \& Temsah M., (2016): Incidence and characteristics of hepatitis $\mathrm{E}$ virus infection in children in Assiut, Upper Egypt. Journal of International Medical Research.Vol.44(5)pp 1115-1122.

7. Ismail, F., Chik, C., Muhammad, R., \& Yusoff, N., (2016): Food Safety Knowledge and Personal Hygiene Practices amongst Mobile Food Handlers 
in Shah Alam, Selangor, Procedia - Social and Behavioral Sciences VOL.222,PP.290 - 298.

8. Lum A., Albrect J., Yaseen M., Litchfield R., \& Ritter-gooder P., (2013): Food-handling practices and knowledge among families with young children. Food protection trends Vol.1pp 358-375.

9. Lundy K., \&Janes S., (2016): Community Health Nursing: Caring for Public Health, $3^{\text {rd }}$ ed, ch 20: Communicable and Infectious Disease, Jones \& Bartlett Learning, Pp.550 .

10. Mahmoud T., Abd El-Ghany N., Hany A., Labeeb S., Kotb S., (2010): Assessment of Home Environment and its relation to Children's Health as a Basis to Design an Eduational Program for their Mothers in Rural Areas in Assiut: Faculty of Nursing: Community Health Nursing, Pp 220204.

11. Maurer \& Claudia M., Smith (2013): Community public Health nursing practice: Health for families and populations, chapter $8,5^{\text {th }}$ ed,st.Lois,Missouri,pp204.

12. McIntyre, L., Vallaster, L., Wilcott, L., Henderson, L., \& Kosatsky, T., (2013): Evaluation of food safety knowledge, attitudes and self-reported hand washing practices in FOODSAFE trained and untrained food handlers in British Columbia, Canada, Food Control VOL.30 PP. 150-156.

13. Mendagudali, R., Akka, K., Swati, I., Shedole, D., \& Bendigeri N., (2016): Knowledge, attitude, and practices of food safety among women of Khaza bazar, the urban field practice area of KBN Institute of Medical Sciences, Kalaburagi, Karnataka. Int J Med Sci Public Health. Vol.5 PP.516-520.

14. Meysenburg R., Albrect J., Litchfield R., \& Ritter-Gooder P., (2014): Food safety knowledge, practices and beliefs of primary food preparers in families with young children .A mixed methods study.Appetite.Vol.73 PP.121131.

15. Parra, P., Kim, H., Shapiro, M., Gravani, R., \& Bradley, S., (2014): Home food safety knowledge, risk perception, and practices among Mexican-Americans, Food Control VOL.37 PP. 115-125.

16.Sani, N., \& Siow, O., (2014): Knowledge, attitudes and practices of food handlers on food safety in food service operations at the Universiti Kebangsaan Malaysia, Food Control VOL.37 PP. 210-217.

17. Sharif L., Obaidat M., \& Al-Dalalah M., (2013): Food hygiene knowledge, attitudes and practices of the food handlers in the military hospitals. Food and Nutrition sciences.Vol.4 pp. 245-251.

18. Siau, M., Son, R., Mohhiddin, O., Toh, P., \& Chai, L., (2015): Food court hygiene assessment and food safety knowledge, attitudes and practices of food handlers in Putrajaya, International Food Research Journal VOL.22(5)PP. 1843-1854.

19. Stenger K., Ritter-Gooder P., Perry C., \& Albrect J., (2014): Amixed methods study of food safety knowledge, practices and beliefs in Hispanic families with young children.Appetite.Vol.83 pp.194-201.

20. Thelwell-Reid M., (2014): Food safety knowledge and self-reported practices of food handlers in Jamaica. Walden University Scholar Works available at http://scholarworks.waldenu.edu/dissertations Part of the Environmental Health and Protection Commons, and the Public Health Education and Promotion Commons.

21. World Health Organization (WHO,2015): the glopal burden of Food borne Diseases available at http:

//www.who.int/foodsafety/areas_work/foodbornediseases/ferg/en. 